\title{
DOES THE SINGLE DRAFT OF COC IN THE SOUTH CHINA SEA MATTERS?
}

\author{
Agus Haryanto $^{1}$, Arief Bakhtiar Darmawan ${ }^{2}$ \\ ${ }^{1}$ Department of International Relations, Universitas Jenderal Soedirman; \\ email: agus.haryanto@unsoed.ac.id \\ ${ }^{2}$ Department of International Relations, Universitas Jenderal Soedirman; \\ email: ariefbakhtiar@rocketmail.com
}

\begin{abstract}
Abstrak
Tulisan ini bermaksud untuk mengelaborasi bagaimana dampak Draf Tunggal CoC dalam proses penyelesaian sengketa Laut Cina Selatan (LCS). Tulisan ini menggunakan konsep International Dispute Settlement Procedures (IDSPs) di mana para pihak berusaha untuk menyelesaikan persoalan berdasarkan hukum internasional. Tulisan ini memiliki argumen bahwa negara-negara di kawasan telah berupaya untuk memiliki mekanisme tata berperilaku sejak tahun 1990-an. Meskipun tahun 2018 negara-negara ASEAN dan Cina telah menyepakati Draf Tunggal CoC mengenai tata berperilaku di LCS, penyelesaian sengketa LCS masih jauh dari kata selesai. Draf Tunggal CoC hanya merupakan kumpulan usulan ASEAN dan Cina. Kelemahan-kelemahan Draf Tunggal terdiri dari kelemahan dari sisi legal status yang tidak menyebutkan secara jelas kewajiban negara-negara anggota dan cenderung tidak ketat karena tiap negara bisa menambah atau menarik usulan masing-masing.
\end{abstract}

Kata Kunci: $\quad$ ASEAN, Draf Tunggal CoC, IDSPs, Laut Cina Selatan

\begin{abstract}
This paper attempts to elaborate on the impact of the Single Draft of CoC in resolving the South China Sea (SCS) dispute. This paper uses the concept of International Dispute Settlement Procedures (IDSPs), where the parties try to resolve problems based on international law. This paper argues that countries in the region have been trying to have CoC mechanisms since the 1990s. Although in 2018, the ASEAN countries and China agreed on a Single Draft of CoC in the SCS, however the settlement of the SCS dispute is far from over. The CoC Single Draft is only a collection of ASEAN and China proposals. The Single Draft weaknesses in terms of legal status are they do not clearly state the obligations of each country to add or withdraw their respective proposals.
\end{abstract}

Keywords: ASEAN, IDSPs, Single Draft of COC, South China Sea 


\section{Introduction}

The problem of overlapping claims in the South China Sea (SCS) is a persistent and critical issue in Southeast Asia. The dispute directly involves five claimants, four are from within ASEAN namely Vietnam, the Philippines, Malaysia, and Brunei and one is The People's Republic of China. Indirectly, however, the dispute involves the rest of ASEAN member states and their respective interests in it (Darmawan and Mahendra, 2018: 79100; Simon, 2012: 997). The dispute has become even more complicated due to linkages to other issues such as China's rise, the threat of regional militarization, and international maritime law debate. To make matter worse, major powers such as the United States, China, and Russia dabbled in the dispute as a mean to exert their influences regarding the freedom of navigation in and over-flight above the area (Pattiradjawane, 2016: 9). Put simply, the dispute is a ticking time bomb that can go off at any minute.

ASEAN states had repeatedly attempted to resolve the SCS dispute through various means. Although the dispute pitches member states against each other, ASEAN has been active in promoting a peaceful resolution (Simon, 2012: 997). In the last three decades, ASEAN and China have been taking part in various discussions in an attempt to establish a Code of Conduct (CoC) regarding the dispute (CSIS Expert Working Group, 2018: 2). Although ASEAN's first statement regarding this issue was made in 1992, the CoC itself was only officially recommended by ASEAN in 1996. In 2002, ASEAN and China finally agreed on the Declaration on the Conduct of Parties in the South China Sea after two years of negotiation. This agreement, however, was not a proper resolution. Three years after the declaration was agreed, the guide of implementation was finalized. The guide, however, would not be signed for another six years with the adoption occurring in 2012. During those years, the tension in the disputed region was a cause for concern, it still is. For example, in 2016, out of suspicion, the Philippines asked the Permanent Court of Arbitration to clarify the status of Spratly and Paracel Islands as well as China's nine-dash line.

Amidst all the incidents, however, the dialogue between ASEAN and China got its second wind in 2017. ASEAN's officials and their Chinese counterparts finally agreed on the framework for the 14th Meeting on the Implementation of the Declaration on the Conduct of Parties in the South China Sea in Manila Augusts 2017. This breakthrough 
earned the coverage of both ASEAN-based (Dancel, 2017) and China-based (Xinhua, 2017) news outlets. A year later, on 2nd of August 2018, Singaporean Foreign Minister Vivian Balakrishnan declared that both parties have agreed on a single draft for the $\mathrm{CoC}$ (CSIS, 2018:2). By tracing the milestones in SCS dispute resolution effort by ASEAN, this article aims to observe the negotiation process of $\mathrm{CoC}$ and to analyse the feasibility of the single draft as a long-term solution. During this time, the problem that often arises in the South China Sea conflict is the absence of a code of conduct. Therefore, since the 2000s, conflicting parties have tried to develop a code of conduct in the southern Chinese Sea. This article argues that the deadlocks in the $\mathrm{CoC}$ negotiation process indicate that the resolution effort is still some way off from creating a binding and clear-cut code of conduct regarding the SCS conflict. This argument is further reinforced by the fact that the single draft contains only suggestions from ASEAN member states but not an actual resolution to the conflict itself.

\section{Concept and Method}

In this paper, the author uses the concept of the International Dispute Settlement Procedures (IDSPs). IDSPs are a set of procedures for making decisions on alleged violations of international legal norms (Zangl et al., 2011: 370). In a conflict, the parties involved and parties outside can be active in seeking a solution. Disputing parties can resolve problems among themselves through bilateral and multilateral negotiation schemes. In several cases, the parties cannot achieve a solution due to the complexity of the issues. Therefore, there are third parties who mediate based on international law. This third party is the party-appointed and agreed upon by the disputing parties to conduct institutionalized negotiations in resolving the disputed issue. Usually, these third parties are parties who are neutral or not directly involved in disputes.

In addition to using third parties, countries can also use international instruments for resolving conflicts. For this reason, international law provides instruments for resolving disputes through this mechanism. For example, we can use the WTO mechanism to resolve trade disputes. Then, the state can also file a general dispute through the International Court of Justice (ICJ) based on which is international treaty law.

Although the mediation mechanism of some issues in relations between countries is precise, in practice, there are differences in implementation (Zangl et al., 2011). In the 
context of territorial disputes, what is questioned by the state is sovereignty. In the context of a maritime dispute, the concept of sovereignty embraced by China is very different from the western model of sovereignty, for example, disputes over the sovereignty of the Spratly Islands and Paracels (Jacques, 2011: 325-326). The idea of maritime sovereignty based on the 1982 United Nations Convention (UN Nations Convention on The Sea/UNCLOS 1982) is the basis of the claims of various Southeast Asian countries for the Spratly Islands and Paracels. On the contrary, China bases its argument on "historical claims." Experts from China argue that: "A juridical fact must be weighed according to the laws of its time, not according to the law in force when disputes arise" (Jacques, 2011: 326-327). In order to overcome this difference of views, since the 1990s, countries in Southeast Asia and China have sought documents on how to behave in the South China Sea. This Code of Conduct (COC) aims to reduce the escalation of conflicts in the South China Sea.

\section{Research Method}

This article uses qualitative historical analysis methods in International Relations. In general, this method attempts to interpret historical facts with a perspective of International Relations (Thies, 2002). In this method, researchers firstly parse the research source that is the primary source of documents and reports on the South China Sea disputes and secondary materials such as news in the mass media. Secondly, researchers read the whole document to determine the sequence of events in the conflict resolution efforts of the South China Sea. Thirdly, researchers' analyses using the theory and concept in international relations - this paper using International Dispute Settlement Procedure (IDSP). Based on the concept of dispute settlement, this paper analyzes the historical fact in the process of negotiation among countries to deal with the code of conduct in the south china sea.

\section{Result and Discussion}

\section{The Deadlock in the Code of Conduct Negotiation}

ASEAN's failure of establishing a single stance on crucial points of the SCS conflict during the 45th ASEAN Ministerial Meeting in Cambodia invoked several interpretations by experts. Some called the failure indicated ASEAN's lack of effectiveness as a regional organization; others, however, see the incident in a better light and called the failure as 
nothing more than a minor disagreement between members. To International Relations experts, especially those in conflict resolution, even ASEAN's mere effort to establish a unified stance on the conflict signified a new phase in the settlement process. The $\mathrm{CoC}$ is expected to form the foundation for regional stability in the long-term (Thuy, 2011:3). A $\mathrm{t}$ the very least, the $\mathrm{CoC}$ could provide a degree of certainty regarding how the disputing parties should behave in the dispute.

Although the negotiation for $\mathrm{CoC}$ did not really take place until much later, the process toward such a breakthrough started as early as March 2000 when ASEAN and China came to a mutual understanding that an agreement of some form was needed on the SCS dispute. Both parties identified four main areas of disagreement: the geographic scope, restrictions on construction on occupied and unoccupied features, military activities in waters adjacent to the Spratly islands, and policies concerning detainment of fisherman found in disputed waters (Thayer, 2012:1). Although this mutual understanding could be seen as a step forward, it was later clear that agreement on those four issues could not be satisfyingly attained even though both parties aware that it will come a long way in imposing long-term peace and stability in the region.

China finally agreed to renew the talk with ASEAN after several concerning incidents including the claim from The President of Republic of China (Taiwan), Lee Teng Hui, that legally, historically, geographically, and realistically, all of SCS including the Spratly Islands, is part of Taiwan's territorial sovereignty. Taiwan's Foreign Ministry on 13 July 1999 also condemned Malaysia's and Philippines's actions in the area. In addition to Taiwan's actions, China was also concerned with the Philippines's actions of sending their warship BRP Sierra Madre to Second Thomas Soal. As their protest was ignored, China retaliated by sending its navy to patrol the area.

After five years of negotiation, ASEAN and China finally agreed to sign the Declaration on the Conduct of Parties in the South China Sea (DoC) in November 2002 in Phnom-Penh. In this declaration, both parties agreed to promote stability, peace, and development in the contested area. Thuy (2011) calls this agreement a bi-multilateralism, a portmanteau of bilateralism and multilateralism since China conducted a dialogue with ASEAN as a regional organization. The declaration's impact is evident from the fact that ever since its signing, no incident of note has happened in the contested area. 
After the declaration in 2002, the next step is naturally to formulate the actual code. The code is considered to be of paramount importance among ASEAN; the 37th ASEAN Ministerial Meeting declared, "We reaffirmed the Declaration on the Conduct of Parties (DoC) in the South China Sea, which we signed with China in Phnom Penh on 4 November 2002, as an important step towards the adoption of the Code of Conduct in the South China Sea that is crucial for promoting peace, security, and stability in the region".

This statement signified ASEAN's seriousness in finalizing the $\mathrm{CoC}$ as a mean to promote peace and stability in the SCS.

To implement DoC, ASEAN and China signed the Declaration on Strategic Partnership for Peace and Prosperity in 2003 which aims to formulate a master plan for more comprehensive cooperation between ASEAN and China to improve the effectiveness of the DoC. Several steps were taken to that end, for example by holding ASEAN-China Senior Officials meeting, enforcing the DoC, reviewing the implementation process, and creating work groups which provided recommendations for the implementation.

During the Joint Working Group Meeting (JWG) in Manila in August 2005, however, ASEAN and China could not agree on the agenda. Whilst ASEAN insisted on creating a draft for border dispute resolution China refused to discuss the matter, insisting that it could only be solved bilaterally with each concerned party. Another mishap between the two was the fact that ASEAN wanted to create an agreement as a unified party while China wanted to talk to ASEAN only after conducting bilateral meetings with "concerned parties." With that, in 2005, China's bi-multilateralism approach on the SCS dispute had been replaced with bilateralism once more (Thuy, 2011: 6; Thayer 2012: 1).

Table 1 - Timeline of the Negotiation process of the Code of Conduct

\begin{tabular}{|c|l|}
\hline Year & \multicolumn{1}{|c|}{ Milestones } \\
\hline 2002 & The signing of the DoC between ASEAN and China \\
\hline 2011 & Guidelines for Implementation of DoC \\
\hline $2011-2012$ & ASEAN formulated the draft for CoC \\
\hline July 2012 & $\begin{array}{l}\text { The failure to agree on the Joint Communiqué during the 45th ASEAN Ministerial } \\
\text { Meeting }\end{array}$ \\
\hline September 2012 & Indonesia proposed "The Zero Draft" \\
\hline May 2013 & China agreed to establish a Joint Working Group (JWG) for CoC \\
\hline
\end{tabular}


Source: CSIS, 2018; Thayer, 2012; Thuy, 2011; and Valencia, 2013. compiled by the authors.

After 2005, no significant development occurred in the SCS dispute. ASEAN and China kept working in the $\mathrm{CoC}$, while the contested region spotted several sporadic incidents. It was between 2009 and 2012 that there was a spike in the number of incidents in the area. One of the most well-known was the clash between a Vietnamese survey ship and three Chinese patrol vessels occurred $120 \mathrm{~km}$ off the south-central coast of Vietnam or around $600 \mathrm{~km}$ south of China's Hainan Island. Vietnam claimed that the Chinese boats deliberately cut the survey ship's cables in Vietnamese waters, but China denied the accusation. The response from ASEAN member states to this incident was the perfect showcase of how member states did not actually have a unified stance. As the relation between Vietnam and China heated up, Malaysia took China's side in the hope of profiting off China's economic boom. Malaysia went further and claimed that China's action in the area was due to American provocations.

A significant development finally occurred in 2010 when ASEAN discussed the dispute through the framework of ASEAN Regional Forum. In the forum, ASEAN tried to create some sort of Balance of Power by inviting the US to participate actively. A year later, in front of the Australian parliament, President Obama made his famous of pivoting and rebalancing towards the Asia-Pacific the Asia-Pacific region, evidence of American commitment to actively participate in the dispute settlement process. This commitment was showcased on the US's participation in the 17th ASEAN Regional Forum. Secretary of State Hillary Clinton declared that The US has an interest in the disputed area in the form of freedom of navigation, access to Asian waters, and to uphold international maritime laws. Clinton also declared that the US supports the collaborative effort of the organization, the implementation of DoC in 2002, the push for the agreement of CoC, and will prepare the effort for confidence-building measures hand-in-hand with the DoC.

China responded to this statement by declaring that they are trying to increase confidence between disputing parties as an effort toward resolution proper. At the same time, however, senior diplomat Yang Jiechi also declared that the dispute could not be discussed at an international level. He also stated that DoC was not an agreement between China and ASEAN as an organization since the dispute can only be resolved by bilateral 
means. Cooperation with ASEAN, he added, have been finalized in the framework of JWG consultations on DoC (Thuy, 2011: 16).

In the 44th ASEAN Ministerial Meeting--which also served as ASEAN Regional Forum--in 2011, China and ASEAN came to an agreement over the Guidelines for the Implementation of the Declaration on Conduct of Parties in the South China Sea. The signing of the guidelines was the most significant breakthrough since the signing of the DoC on November 4th, 2002. It is also the highlight of Indonesian Chairmanship of ASEAN in 2011. The agreement opened the possibilities of implementing the declaration through cooperation between ASEAN and China in the contested area as well as served as the budding for a Regional Code of Conduct in the South China Sea which would serve as an operational preventive measure and effective behavioural regulation.

On July 2011, the framework for the implementation of the DoC was adopted as a pathway toward interparty dialogue. In the application, all agreed frameworks must be reported to the ASEAN-China Ministerial Meeting. China, however, remained adamant of holding a talk with ASEAN regarding the SCS dispute only at the "appropriate time and situation." Such a position made it difficult for ASEAN members who have a stake in the dispute such as the Philippines and Vietnam.

In January 2012, the Philippines proposed a draft informally called "Philippines Draft Code of Conduct." The eight-page draft proposed to transform the SCS into a "Zone of Peace, Freedom, Friendship, and Cooperation (ZOPFF/C). The Philippines proposed the promotion of cooperation in the area, a permanent working committee to implement ZOPFF/C, to reaffirm the use of UNCLOS 1982 in the resolution process, as well as proposing a dispute settlement mechanism. The draft was seriously discussed in ASEAN Senior Officials Meeting in 2012 in which member states were polarized into two camps. Cambodia proposed to invite China to the discussion so that if the meeting managed to formulate draft, China would be behind it as well. The Philippines and Vietnam, on the other hand, rejected the proposal as they believe that ASEAN should only hold a talk with China as a unitary actor and as such, the talk should only be held when all member states have adopted the same stance.

On the seventh day of the meeting, it was decided that "[they] agreed to submit the draft ASEAN proposed key elements of the regional Code of Conduct in the South China Sea to the ASEAN SOM for consideration." These key elements were discussed in the 
45th ASEAN Ministerial Meeting in July 2012. In the meeting, Kao Kim Hourn, Cambodian Foreign Minister, declared that ASEAN's senior officials have agreed to hold a meeting with their Chinese counterparts to talk about the South China Sea.

In the aforementioned Ministerial Meeting, Indonesia took an active role. Foreign Minister Marty Natalegawa drafted a joint communiqué alongside Anifafh Aman from Malaysia, Albert del Rosario from the Philippines, and Pham Binh Minh from Vietnam. The draft, however, could not be agreed on time due to a crowded agenda. According to Thayer (2013) what happened at the meeting was caused by a deal made by China National Offshore Oil Company to explore mining prospect in Vietnamese EEZ.

During the 45th Ministerial Meeting in Cambodia, Cambodian Prime Minister Hun Sen emphasized the importance of realizing ASEAN Community 2015 as a priority. He also declared that the implementation of DoC-including concluding the $\mathrm{CoC}$ negotiation-should be taken seriously. Unfortunately, similar to the year before, the meeting failed to agree on the joint communiqué.

This failure piqued the interest of the world. Johnson (2012: 65) claimed that the failure was due to Hu Jintao's visitation to Cambodia just before the 20th ASEAN Summit in an attempt to prevent the SCS from being discussed in the summit. Cambodia, which held the chairmanship at the time, then decided to refrain from talking about the issue. This turn of events was unfortunate considering that the Philippines, Vietnam, and Thailand have drafted a revised version of the CoC to replace the 2012 version. Cambodia further muddied the water by suggesting that the draft should be discussed with China first to prevent a fall-out between ASEAN and China.

ASEAN's failure to reach consensus was responded by Indonesian President at the time, Susilo Bambang Yudhoyono, by instructing Foreign Minister Natalegawa to try and unify ASEAN members' stances through shuttle diplomacy.

\section{The Zero Draft Code of Conduct}

ASEAN's failure to agree on the 2012 version of the $\mathrm{CoC}$ was responded with a revised draft proposal from Indonesia. According to Thayer (2013), the step was not only Indonesia's attempt to unify the stances of ASEAN members but also to show the image of a unified ASEAN to the world. The attempt was mostly carried out through Natalegawa's shuttle diplomacy to five capitals--Manila, Hanoi, Bangkok, and Phnom 
Penh within mere two days (Natalegawa, 2013; Thayer, 2013: 5). The shuttle diplomacy was a moderate success, and it gave birth to six-principles regarding the SCS dispute.

The principles, as revealed by Nor Hamhong as ASEAN Chairman in July 20: (1) the full implementation of the Declaration on the Conduct of Parties in the East Sea (DoC), (2) the Guidelines for the Implementation of the DoC, (3) the early conclusion of a regional Code of Conduct in the East Sea (CoC), (4) the full respect of the universally recognised principles of International Law, including the 1982 United Nations Convention on the Law of the Sea (UNCLOS), (5) the continued exercise of self-restraint and non-use of force by all parties, and (6) the peaceful resolution of disputes in accordance with universally recognised principles of International Law, including the UNCLOS. (Natalegawa, 2013; Thayer 2013: 6)

China responded to this effort by sending their Foreign Minister Yang Jiechi to Indonesia, Brunei, and Malaysia. During a press conference in Jakarta, he declared that China wanted to implement DoC based on a consensus. During the meeting with Malaysian Foreign Minister Y.B. Datok Sri Anifah Aman in Kuala Lumpur, Aman stated that since there is still a problem of overlapping claims among ASEAN member, ASEAN must first resolve this problem among themselves before starting a discussion with China (Thayer 2013: 6). The statements shed light on the internal condition of ASEAN and improve China's position in the negotiation.

On September 27, 2012, Indonesia presented the "Zero Draft a Regional Code of Conduct in the South China Sea" to ASEAN Foreign Ministers during a UN meeting in New York. The draft drew heavily from three previous agreements: 2002 DoC, ASEAN's proposal on CoC in 2012, and the aforementioned six principles (Thayer, 2013: 7)

The draft consists of nine articles; in general: (1) basic principles, (2) the objective of $\mathrm{CoC}$, (3) basis for the implementation of $\mathrm{CoC}$, (4) geographical scope for $\mathrm{CoC}$ implementation, (5) provisions regarding territorial claim of the SCS area, (6) CoC implementation, (7) mechanism for monitoring and reporting for $\mathrm{CoC}$, (8) dispute settlement mechanism, and (9) final provisions regarding the review of $\mathrm{CoC}$ every fiveyear as dictated by the consensus.

Natalagewa stated that the Zero draft would not be retroactive which means any actions committed by a signatory before the draft became official would not be considered as a violation. For example, both Vietnam and the Philippines have conducted several 
joint military trainings with the US. Although the Zero draft prohibits these actions, they would not be reported as violations as it is committed before the draft became official.

\section{Table 2 - The Zero Draft Code of Conduct on South China Sea Dispute}

Important Articles in the Zero Draft:

Objective (Article II) and basic provisions (Article III):

1. Promote confidence and prevent incidents based on the principles of the Declaration of Conduct.

2. Commitment to respect freedom of navigation in and over-flight above the South China Sea.

3. Settle territorial and jurisdiction dispute in the South China Sea through peaceful means on the basis of international law and UNCLOS.

4. Commitment to exercise self-restraint in activities that would complicate or escalate disputes and affect peace and stability.

5. Respect for the Exclusive Economic Zone (EEZ) and continental shelf of the coastal states as per UNCLOS 1982.

6. Respect for the $\mathrm{CoC}$ and the taking of actions consistent with it.

7. The encouragement to other countries to respect all the objectives and the principles in the CoC.

Area of Application (Article IV)

Without prejudice to existing claims, $\mathrm{CoC}$ will be implemented on entire unresolved maritime boundary areas of the parties concerned in the South China Sea.

Territorial Claims in the South China Sea (Article V)

Nothing in the CoC shall be used to:

a. Refute any party's claim to strengthen one's own claim on the disputed area.

b. Compromise the position or claim of any party to territory (or islands) in the South China Sea using or based on a recognition/refutation by a third party.

$>\quad$ No action or activity is applicable if provisions from the $\mathrm{CoC}$ are brought upon by force.

$>\quad$ All parties shall commit to the resolution of both territorial and jurisdictional disputes by peaceful means without resorting to force or a threat of force, through amicable consultations between sovereign states directly concerned in accordance with universally recognized principles of international law, including, but not solely, the 1982 UNCLOS.

Rules and Procedures to Resolve Incidents (Article VI, Section 2)

concerned parties file a chronological report

post-incident talks must be held as soon as an incident occurs

a "hotline" communication line between foreign ministers shall be established 


utilizing existing Sino-ASEAN diplomatic channel
involving the High Council of the Treaty of Amity and Cooperation in Southeast Asia
any unresolved incident may be referred to an appropriate international dispute settlement
If the issue cannot be resolved within this ASEAN framework, then the parties could use the mechanisms
provided by international law, including but not limited to UNCLOS.

Valencia, in his article What the 'Zero Draft' Code of Conduct for the South China Sea Says (and Does not Say): Navigating Differences published in 2013 criticized Indonesia's suggestion in the draft. According to him, the suggestion was unrealistic and was very likely to be rejected by ASEAN. He claims that Indonesia's position in the dispute is ambiguous as Indonesia probably has an overlapping jurisdictional claim with China in the area around Natuna. In Valencia own words:

"A fundamental problem facing Indonesian officials is that China does not really believe Indonesia is neutral in this affair. In fact, Indonesia and China probably have overlapping jurisdictional claims in the South China Sea, depending on the meaning of China's historical "nine-dashed line," which Indonesia has formally criticized at the United Nations" (Valencia, 2013 :73-74).

In-depth, Valencia (2013: 78) reviewed the draft and concluded that it still has many flaws. First, he regards the term "parties" to be ambiguous, as it can refer to ASEAN member states or ASEAN as an organization. Second, he considers the clause "A commitment to use the area for 'peaceful purposes' only" "somewhat controversial" but without mentioning any specific. Third, the clause "A commitment to specific confidence-building measures like dialogue, prior notification of military activities in waters claimed by others, voluntary exchange of information etc.; A commitment to endeavour to determine and agree which features and areas are in dispute and which are undisputed."; according to Valencia, the clause-which was suggested by the Philippines - is controversial as it implies that disputing parties can conduct military activities in areas claimed by others as long as they give a heads up. Fourth, the clause "promoting 'provisional arrangements of a practical nature' as provided in the DoC and UNCLOS"; according to Valencia, the clause could include "sharing or joint development of resources in areas of overlapping claims." Fifth, the clause "the parties will not take 
any unilateral action in disputed areas that would jeopardize or hamper the reaching of a final agreement regarding the disputed area" is redundant since it is already in the UNCLOS. Finally, Valencia believes that the document should be signed by the heads of state to highlight the importance of the document and the commitment to its provisions.

In conclusion, Valencia thinks the draft is "a step forward" and it does contain unprecedentedly bold proposal. However, this boldness would make it hard for all claimants within ASEAN to agree to the entirety of the document, let alone China. Such a deadlock would make it difficult for other parties that have a stake in the disputed are-such as the US. In short, Valencia calls the draft "a bridge too far."

Regardless of the overreaching nature of the draft, Indonesia still showed admirable commitment to see it through during the 45th ASEAN Ministerial Meeting. Thayer (2013: 11) says that Indonesia has taken a crucial role during a time of crisis for ASEAN. In the meeting, ASEAN member states were involved in a heated debate to the point that Indonesia offered a "non-paper" CoC. Indonesia, with Singapore's support, also attempted to compromise in the meeting by formulating a joint communiqué. It was a controversial move at the time but it was also the most logical way to make conflicting parties meet halfway. Thayer concludes in his article:

"During the recriminations between Cambodia and the Philippines at the 45th AMM and later in the year Indonesia stepped in and played a crucial role in forging consensus among ASEAN members on a Regional Code of Conduct in the South China Sea. During the heated debate at the 45th AMM Retreat Indonesia offered to submit a 'non-paper' on the CoC. Indonesia and Singapore both attempted to broker a compromise over the wording of the controversial AMM joint communiqué" (Thayer, 2013: 11).

Indonesia's objective with the draft can be inferred from Natalegawa's statement during his 2013 Annual Ministerial Press Release which stated that the draft was merely a beginning. The draft was meant to reel ASEAN and China back to the table. He stated:

"When doubts appeared regarding ASEAN's unified stance on the SCS issue, Indonesia carried out shuttle diplomacy which in mere thirty-six hours consolidated ASEAN's with the six-point principles. Next, Indonesian diplomacy pushed for the full implementation of the DoC--which include a regional code of conduct--through 
agreement on the basic elements of the code as well as the formulation of an early draft of CoC" (Natalegawa, 2013).

Indonesia meant to "encourage the establishment of diplomatic communication so that conflicting parties will prioritize diplomatic channel for dispute settlement" (Natalegawa, 2013). Indonesia wanted to erase the image that peace and stability in AsiaPacific are under threat from an in-fighting between regional powers. Indonesia also wanted to manage the potential conflict so that it can be turned into potential cooperation. According to Natalegawa, such a paradigm is a novelty in the SCS dispute.

The Zero Draft is actually Indonesia's way of testing the water and sees the reactions of ASEAN member states to the failure in Cambodia. Although the Zero Draft was not officially adopted yet, it does succeed in reeling concerned parties to a discussion which may yield a legally binding document. According to Indonesia, China is in a desperate position when Modi seemed to have inched closer to Japan as indicated by Modi's choice of making Japan his first country to visit after his inauguration as PM. In addition to that, the US is also perceived to be a threat by China when they established political and security cooperation with the Philippines and Vietnam. In such a desperate position, the logical choice for Beijing was to embrace ASEAN and the zero draft consequently became a rational choice, not only for ASEAN but also for China.

\section{Evaluating the Single Draft}

In August 2018, ASEAN and China agreed on the Single Draft of CoC. It was only a year before, in August 2017, that ASEAN and China started to entertain the possibility of agreeing on the $\mathrm{CoC}$ framework. Chinese Foreign Minister Wang Yi affirmed that agreeing to the framework indicates China's willingness to promote stability in SCS. Nevertheless, Wang $\mathrm{Yi}$ also asserted that $\mathrm{CoC}$ is not an instrument to resolve territorial conflict and maritime delimitation issue in SCS. Instead, Wang Yi saw the code as an attempt at promoting confidence, willingness to cooperate, and an environment suitable for the pursuit of peaceful resolution. Although the framework itself does not explicitly explain to what extent the CoC will be legally binding, ASEAN Secretary-General Le Luonh Minh hoped that it would pave the way toward substantial negotiations. The Philippines, as one of the claimants who desired a binding code of conduct, also declared that they would be open to take steps that may improve the binding nature of the $\mathrm{CoC}$ (Dancel, 2017) 
The beginning of the finalization of the CoC started in August 2018 during the 51st ASEAN Foreign Ministers Joint Communiqué in Singapore. In the communiqué, senior officials from ASEAN member states agreed on several additional points in relation to the CoC (Thayer, 2011; Thayer, 2018). First, all parties shall uphold the CoC negotiating text during the negotiation process. Second, the negotiating text will become the basis for further negotiations. Third, all parties possess the right to consult internally with their respective domestic institutions and to register new suggestions during the negotiation process.

Based on those agreed points, the single draft $\mathrm{CoC}$ was compiled. The draft consists of 19 A4-sized pages and is divided into three parts: preambular provisions, general provisions, and final clauses. The draft, however, still suffers from one of the earliest disagreements among member states as it does not clearly define the geographical scope of the "South China Sea." Indonesia suggested that the concerned parties respect the Exclusive Economic Zone and the continental shelves of coastal states as per the UNCLOS 1982. Vietnam, on the other hand, simply stated that the CoC must encompass all the features of the dispute and all the contested area as per the UNCLOS 1982.

From the perspective of legal status, the single draft does not recommend $\mathrm{CoC}$ as an agreement proper under international law. In page five point 15, the draft emphasizes that " $\mathrm{CoC}$ is not an instrument to settle territorial disputes or maritime delimitation issues." Although the draft often refers to international law in general and UNCLOS in particular, the draft does not explicitly express obligations for signatories' states to abide by the provisions in UNCLOS; for example, to use arbitration. The single draft also tends to be flexible as concerned parties are allowed to add to or remove their suggestions from the draft. All things considered; the single draft does not serve as a legal basis for dispute settlement mechanism. That being said, in points $f$ and $g$ in page 12 regarding incident management, Indonesia offers:

"The Parties agreed, as appropriate, to resort to the High Council of the Treaty of Amity and Cooperation (TAC), at the consent of the Parties concerned, to settle any dispute relating to incidents that may arise in the South China Sea; The Parties agreed that any unresolved incident may be referred to an appropriate international dispute settlement mechanism, at the consent of the concerned Parties". 
Indonesia's recommendation was one of the most fleshed out compared to any other participants. Myanmar, for example, only suggested concerned parties to settle through calm and constructive means. Vietnam suggested concerned parties to resolve the conflict "through friendly negotiations, enquiry, mediation, conciliation and other means as may be agreed by the disputing Contracting Parties." While China suggested joint military exercise and hotline communication lines between the institutions-in-charge of every party.

However, even with the absence of dispute settlement mechanism in the SCS issue, the single draft still expresses the obligations of all parties to promote maritime cooperation among each other. Except for China, the draft includes cooperation in these five fields: marine environmental protection, marine science research, navigation security, communication on the sea, and measures against transnational crimes. Cambodia added the importance of connectivity on the sea while China suggested the development and conservation of fishery resources, cooperation on enforcing international law and maritime security, navigation security and search and rescue operations, marine science research and marine environmental protection, marine economy, and marine culture.

\section{Conclusion}

When the early negotiation process for CoC was taking place in early 2000s, ASEAN and China could not agree on four important points. First, geographical scope; second, prohibition of construction on the SCS; third, military activity in and around the Spratly Islands; fourth, whether it is acceptable to arrest and detain fishermen operating in the disputed area. The failure led to the creation of non-binding DoC in 2002. Similar thing re-occurs in the negotiation process for the Single Draft of CoC. Geographical scope is not clearly defined and the draft does not prohibit infrastructure-building or military activities in the area. Regarding fisheries resources, concerned parties only agreed to establish maritime cooperation.

As such, at its very essence, the single draft is a mere compilation of suggestions from ASEAN member states and China. If anything, the draft serves only as a reference in the implementation of CoC. The talk for the CoC began in 1996, in the aftermath of China's occupation of the Mischief Reed in 1995. For a similar incident to occur before 
another breakthrough is made in the dispute settlement process would be the last thing ASEAN needs.

\section{References}

CSIS (2018) Defusing the South China Sea Disputes A Regional Blueprint. Washington DC: CSIS.

Dancel, R. (2017) 'Asean, China adopt framework of code of conduct for South China Sea , SE Asia News \& Top Stories - The Straits Times', 6 August. Retrieved from: https://www.straitstimes.com/asia/se-asia/chinas-foreign-minister-says-maritimecode-negotiations-with-asean-to-start-this-year (Accessed: 29 May 2020).

Darmawan, A. B. and Mahendra, Lady (2018) 'Isu Laut Tiongkok Selatan: Negaranegara ASEAN Terbelah Menghadapi Tiongkok', Jurnal Global \& Strategis, 12(1), p. 79. doi: 10.20473/jgs.12.1.2018.79-100.

Jacques, M. (2011) When China Rules The World (Ketika China Menguasai Dunia): Kebangkitan Dunia Timur dan Akhir Dunia Barat. Edited by N. Cholis and J. Sumarwoto. Jakarta: Penerbit Buku Kompas.

Johnson, A. N. (2012) A Bilateral Analysis of the South China Sea Dispute: China, the Philippines, and the Scarborough Shoal Recommended Citation. Florida International University. doi: 10.25148/etd.FI12071113.

Natalegawa, M. (2013) An Indonesian perspective on the Indo-Pacific. Retrieved from: https://www.thejakartapost.com/news/2013/05/20/an-indonesian-perspectiveindo-pacific.html (Accessed: 29 May 2020).

Pattiradjawane, R. (2016) 'Arbitrase Laut Selatan: Ancaman Militerisasi Regional', Kompas, 11 July.

Simon, S. W. (2012) 'Conflict and diplomacy in the South China sea the view from washington', Asian Survey. University of California Press, 52(6), pp. 995-1018. doi: 10.1525/as.2012.52.6.995.

Thayer. Carl (2018) ASEAN and China Set to Agree on Single Draft South China Sea Code of Conduct - The Diplomat. Retrieved from: https://thediplomat.com/2018/07/asean-and-china-set-to-agree-on-single-draftsouth-china-sea-code-of-conduct/ (Accessed: 29 May 2020).

Thayer, C. A. (2011) 'Chinese Assertiveness in the South China Sea and Southeast Asian Responses', Journal of Current Southeast Asian Affairs, 2(30), pp. 77-104.

Thayer, C. A. (2012) 'ASEAN'S Code of Conduct in the South China Sea: A Litmus Test for Community-Building?', The Asia-Pacific Journal | Japan Focus, 10(34).

Thayer, C. A. (2013) 'South China Sea in Regional Politics: Indonesia's Efforts to Forge ASEAN Unity on a Code of Conduct', in 3rd Annual Centerfor Strategic \& International StudiesConference on "Managing Tensions in the South China Sea," . Washington DC: CSIS. Retrieved from: https://csis-website-prod.s3.amazonaws.com/s3fspublic/legacy_files/files/attachments/130606_Thayer_ConferencePaper.pdf 
(Accessed: 29 May 2020).

Thies, C. G. (2002) 'A Pragmatic Guide to Qualitative Historical Analysis in the Study of International Relations', International Studies Perspectives. Oxford University Press, 3(4), pp. 351-372. doi: 10.2307/44218229.

Thuy, T. (2011) Recent Developments in the South China Sea: Implications for Regional Security and Cooperation. Retrieved from: www.aseansec.org/1196.htm (Accessed: 29 May 2020).

Valencia, M. J. (2013) 'What the "Zero Draft" Code of Conduct for the South China Sea Says (and Doesn't Say) ', Global Asia, 8(13). Retrieved from: https://www.globalasia.org/v8no1/feature/what-the-zero-draft-code-of-conductfor-the-south-china-sea-says-and-doesnt-say mark-j-valencia (Accessed: 29 May 2020).

Xinhua (2017) 'Maritime trade through South China Sea booms despite territory disputes - Xinhua | English.news.cn', 5 August. Retrieved from: http://www.xinhuanet.com/english/2017-08/05/c_136502038.htm (Accessed: 29 May 2020).

Zangl, B. et al. (2011) 'Between law and politics: Explaining international dispute settlement behavior', European Journal of International Relations. SAGE PublicationsSage UK: London, England, 18(2), pp. 369-401. doi: $10.1177 / 1354066110389832$. 